\author{
Bukurie Mustafa (North Macedonia) \\ Institute of Spiritual and Cultural \\ Heritage of Albanians - Skopje \\ bukurie_m2007@hotmail.com
}

\title{
TRANSFORMATION OF THE ETHNICAL AND RELIGIOUS FUNCTION OF THE TRADITIONAL COSTUME OF ALBANIANS IN MACEDONIA DURING SOCIALISM
}

\begin{abstract}
In the ethnographic analysis of the Balkans, the traditional costume commonly represents a distinguishing feature of national identity, as well as an expression of the historical and cultural milieu of the peoples that live here. However, what happens when the ethnical and national identity of the costume transmogrifies into the cultural identity of a system and an era that, in turn, introduces changes to the traditional costume itself?

This cultural and ethnographic transformation in different historical periods has been conditioned by various types of institutional interventions for discovering methods and forms, administered through legislative measures, even bans in order to provide legislative protection of such material cultural goods that belong to a certain people. In this case, by offering a chronological, historical overview, we describe the transformation of part of the clothing culture as an expression of a system such as the system that introduced the Law on Banning Niqabs and Burqas, published in the Official Journal of the Socialist Republic of Macedonia (no. 1, January 12, 1951).

In a broader context, laws that do not consider clothing to be an expression of cultural diversity or national identity, but raise it as an issue for the society and the state, are enacted even today in a large number of European countries.
\end{abstract}

Key words: traditional costume, underhat, qeleshe, terleme, terlik, burqa, niqab.

Throughout its history, Macedonia has experienced various political systems, and in each system there have been attempts to impose different rules and principles in the life of the communities in the region. The plethora of old photos of the city bazaars symbolize an objective chronological overview of the cultural development of the various communities in a region, which also includes the costume that has been traditionally worn throughout the centuries. Such photos have usually been considered as evidence and a historical snapshot of a 
certain era, since they retell the past, while these types of sources have frequently been, relatively speaking, the bone of contention when it comes to the way the cultural and national identity are perceived in this geographic areal. The variety of the traditional costume is considered an obvious distinguishing feature, but it is simultaneously part of the national and religious affiliation of the local population, where a variety of cultures and ethnicities are intermingled, and in this context the traditional costume showcases the national features. One cannot analyze the big picture by looking at the issue from a narrow perspective, bearing in mind that the different rulers who have swapped places in the Balkans have not only introduced novel administrative and political establishments, but have also influenced the general cultural blueprint of the various communities, thus bringing about changes. The traditional costumes express the ethnical and religious identification of those who wear them, and clothing, or parts of clothing, has commonly been used to articulate the population's social and cultural diversity.

The peoples in the Balkans have been defined in various ways in order to encapsulate their ethnicity, but the basic thesis is that "they dance the same national dances, they eat the same food, they speak the same language and they get together to do selfsame activities" (McCarthy 2017: 47). When looking for the sameness, but, at the same time, for what is idiosyncratic for each of the peoples in the Balkans, an image of multiculturalism was created or, perhaps, nationality was determined by analyzing the different types of traditional costumes, often identified on the basis of the distinctive hats, that are definitely the most obvious symbol of national identification. In the historic development of the traditional costume of Albanians, the most distinguishing feature has always been the fact that they wear the white qeleshe, that has become the all-encompassing symbol of the nation, even though that has been subject to change over the course of time. Thus, the Turkish fez can be found in certain visual representations, but it was used more as a fashion accessory and it did not reflect the national awareness of Albanians. However, when the hat is used as a means of distinguishing a certain religious affiliation, and when that process is taking place over a longer period, wearing a black hat was typical in the Albanian ethnic space; this hat is worn even today, and nobody is certain about its origin. Such changes to the traditional costume cannot be examined outside of the bounds of historical and political circumstances. The influence of the Ottoman culture, or, in a broader sense, of Eastern cultures that have been present in this region for a long period, has permeated the culture of everyday life within the communities in the Balkans.

A pivotal component of the clothing, which had its heyday in a certain period, was the fez, that according to Petar Skok was used by Christians and Muslims alike: "All religions wear it" (Skok 1971: 513). The etymology of the term $f e z$ is related to the Moroccan city of Fez, where this type of hat was crafted for the first time. The fez is scarlet red or sometimes black with a tassel attached to the middle of the top. In 1826, the fez became part of the Turkish military uniform, and later on it was worn by the other people. In our country, i.e. in 
this region of the Balkans, sultan Mahmud II adopted the fez by decree, thus making it compulsory for the administration regardless of religious affiliation (Ibrahimi 2017: 248). A number of communities were aware of it as a type of hat and it was considered to be a symbol of prestige, which was pronounced in the urban areas, and it was virtually absent from clothing culture in the isolated, rural regions. Albania was also not excluded from this cultural influence, but after it claimed its independence in 1912, the situation changed. Andromaqi Gjergji believes that the period between 1912 and 1944 was full of changes in terms of the traditional costume and symbolism. She states that the changes had political background and that it was illogical to follow Turkish clothing fashion in an era when the Albanian state was struggling for affirmation and consolidation and had proclaimed its independence, since it was taken as "a sign of conservativism and an unpatriotic gesture, above all in regards to men" (Gjergji 2005: 69). The political influence coupled with a tendency to create a new, modern state resulted in concrete measures being taken and enactment of laws that banned the wearing of the fez. So, in 1925, Turkey enacted a law that banned the wearing of the fez as part of Kemal Atatürk's reforms, who desired to create a modern state (Dizdar 2005: 270). In Albania, this ban was introduced a couple of years later: "In 1929 the government issues a decree to ban the fez among men and the niqab and chador worn by Albanian Muslim women in many cities throughout the country" (Gjergji 2005: 69). This demonstrates the gravity of the issue of oriental dresses, that was suddenly discarded because it was deemed to be conservative and unacceptable in a modern society, even in a lay state. The situation was the same in the other Balkans countries, which strived for creating independent states, identified through national and state symbols.

However, the fate of Albanians in Macedonia was different. They lived through various regimes, such as the Kingdom of Serbs, Croats and Slovenes (which would later become the Kingdom of Yugoslavia), the wars, occupations, and then the creation of socialist Yugoslavia, which also had bearing on the gradual loss of the Albanian national symbol, the qeleshe. It was precisely the symbolism and national belonging conveyed by means of the qeleshe that resulted in having the qeleshe replaced by other types of hats. The research and the interviews carried out with the older generation bear witness to that era. One of the interviewees, born in 1928, had lived through Bulgarian occupation, and when I asked him when the hats, i.e. the qeleshe was changed in the village of Patishka, he replied: "When the Bulgarians came (the second time they were in power), the Bulgarians made this, we call them tërllok, they brought the canon law". The fact that this change was imposed, apart from the testimonials of the inhabitants, can also be gleaned from the historical texts about this era: "In a certain period in Skopje, the Albanians were disallowed to wear the red fez nor the white hat of the Albanians (the qeleshe). The German authorities were well informed about a craftsman who made his living in Skopje by selling white hats. He was arrested in broad daylight and he received a beating by stick so hard that

1 Interview with Istref Beqiri, village of Patishka (1928 - 2015), conducted by Ibe Mustafa and Bukurije Mustafa in Skopje, on January 15, 2012 r. 
he passed away the following day" (Asani 2013: 37). The image of the Albanian slowly began to morph, the qeleshe was replaced with a type of a black hat, made out of cloth, that resulted as well in identity confusion with the Macedonians of Islamic faith. The new hat, called tërllok/terleme, as part of the clothing culture, gained momentum quickly and appeared in other regions in Macedonia $^{2}$, despite the fact that nobody can explain the history of this development or where the hat comes from, and they themselves do not know why they are wearing that type of hat. They do not believe it to be something alien. The hat is interpreted in different ways. A hat salesman at the Skopje old bazaar says that the hat is $\mathrm{Greek}^{3}$, which is an unsubstantiated theory. A Turkish university professor claims that this type of hat has been recorded in Anatolia and that it was used "for bowing" and, in his view, it is probably "Turkish"4. The noun tërllok is used only colloquially and is not accepted in formal Albanian, and this word cannot be found in a single dictionary or encyclopedia. In Turkish, the term takke, which means 'hat', is used, and it serves to absorb sweat after a day's work so that the head does not get cold. It is made of cloth, fabric or silk (Yilmaz 2010: 622). The etymology of the word points to an underhat which was used for absorbing sweat and it was usually worn by Muslims. The Orientalist Muharrem Yahya claims that the term tërllok is an amalgamation of two elements: ter, which means "sweat" in Turkish and the suffix -llk/-llëk/-lëk, which signifies "an instrument". Macedonians of Islamic faith use the term terleme (Turkish), which means "sweat"; the root of the word is the same in both Macedonian and Albanian. However, the semantics of the lexeme tërllok, or the form terleme to be precise, which in Turkish is used to signify "being sweaty", but not in regards to wearing hats is still an issue (Korça 2009: 555). The terms tërllok or terleme are used figuratively and they may be only loanwords in Albanian. It is odd that I have not yet come across any written information about this type of hat. Some other sources, which cover the topic of the traditional costume in the Dinaric Region, assert that the peoples of Croatia and Bosnia used to wear taller, scarlet-red hats on top of white linen hats, or they were knitted using a crochet hook and cotton, and this type of underhat is known as chulah or bjelokapa ${ }^{5}$. Apart from the black hat, known as terleme or tërllok, there are also white hats bearing the same name, that were knitted using a crochet hook or were most frequently brought back from the Hajj, as a gift for somebody

2 It is worth pointing out that terleme is worn in Skopje, Tetovo, Gostivar and $\mathrm{Ku}-$ manovo, but it is not recognized as part of clothing culture in Debar, Kichevo, Struga, Resen and Bitola.

3 According to a Skopje hat seller, the terleme is a Greek hat worn by artisans, the rich people, and one of the oldest tailors in the city had told him that it was Greek. The tailor himself used to wear one just for pleasure, and the passers by would greet him using the Turkish merhaba, thinking that he was Muslim because of the hat, i.e. the tërllok /terleme that he wore. $\mathrm{He}$ would frequently state himself that "the hat is his" in the sense of religious affiliation. Such information is merely speculation, it cannot be proved. An interview with Abdilmexhit Mustafa, born in 1949. The interview was conducted on October 3, 2016, by Bukurie Mustafa and Rini Useini in the Shapkar shop in the Skopje old bazaar.

4 Hakan Turkan, „Karabük Üniversitesi“, sector: history.

5 Narodni.net/dinarske-narodne-nosnje 
else. This type of hat is most commonly worn by the younger population during religious rituals.

The modification of the traditional costume, as well as the novelties and the factors that influenced it, are also evident in the female traditional costume, which has been subject to constant change, in all probability due to religion, as well. Thusly the black coat, called terlik, also became part of the traditional costume. The etymology of the lexeme terlik also has no connection with its basic meaning in Turkish, "slipper". This term is also absent from formal Albanian, but it is used colloquially to signify the black coat. According to the explanation by Abdulah Škaljić, the term terluke/terluci is used in Bosnian culture to signify women's slippers made of red tanned goatskin leather (sahtijan) or from yellow hide (kaysar), which have gold, silver or silk-threaded embroidery on top (Škaljić 1966: 612). In modern Turkish, terlik is used for all types of slippers (Korça 2009: 555). Terlik is also part of the traditional costume of female Macedonians of Islamic faith, who cannot be distinguished from Muslim Albanian women on the basis of the black coat, similar to the example of men who wear tërllok/terleme. During a certain period in the past, as a result of ignorance about this region, as well as about the people of these villages, no distinction was made between them, but the same term, Torbeshi, was used for everybody.

There have been accounts of a time when the village women walked free, in traditional costumes, without being covered. One of our collocutors recounts: "They would walk in our place without a terlik, without coats, the terlik was black and thin... Maybe there are such women in the village now, too... Without

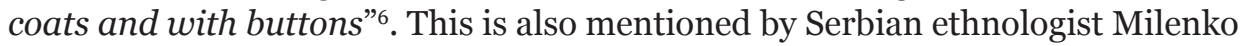
S. Filipovic, who visited the region in 1930. He visited the village of Patishka and, in his ethnologic research, he goes on to say: "Initially they all wore the traditional costume which is worn today in Reka, and the Muslim women did not hide. They would visit each other, and the Muslim women did not hide from the Orthodox men. The Muslims who traveled abroad to Constantinople and Bursa in order to earn money for their families were the first to cover their wives. At the beginning, they would only have a burqa when leaving the village. The Orthodox women until recently wore the traditional women's costume from Reka (they still do so now, on occasion), but casual, city clothing has entered the culture. While there were Serbian men in the village, they behaved in the same way as the Arbanasi in every aspect. The brides, regardless if they were Arbanasi or Serb, would have the same clothing, and on the day of the wedding they would wear a red dulak" (Filipovic 1931: 169). The ethnic affiliation in terms of the research in this village in particular is an issue, but in reality their traditional costume did not differ at all, even when it comes to the qeleshe, which is confirmed by the photograph within the study "Patishka" (Filipovic 1931: 166).

The fact that the Islamic traditional costume, which was brought from Constantinople, was accepted, was exemplified by another type of cape called biniş, that was red and covered the head and the entire body of the bride; it had

6 Interview with Istref Beqiri, village of Patishka (1928 - 2015), conducted by Ibe Mustafa and Bukurije Mustafa in Skopje, on January 15, 2012 г. 
no specific fit, as the village women told me, and it was used exclusively on the day the bride was taken while mounted on a horse. Even in the village of Patishka there was only one such cape and it was handed over between brides (Mustafa, Murtezani, Useini 2017: 45).

During Ottoman rule in this region, the use of burqa and niqab also gained in popularity, in order to show Muslim affiliation, as a consequence of religious influence, that continued to be worn even after the war. People can seldom tell the difference between these two types of traditional costumes. Škaljić is more precise in terms of the description and etymology. The term for burqa, or feredze, comes from the Arabic word vëredža, and he defines it as a type of cape used by women, a coat made of black or dark-blue felt that Muslim women would wear when going out of their homes. Apart from the burqa, they would use yaşmak and çember ${ }^{7}$, and when going on longer journeys, they would wear pecha (Škaljić 1966: 279). Zar, which also comes from Arabic, initially meant "a curtain". It represents a women's cape that the Muslim women used to wrap themselves in and then leave their homes covered in that manner. It is important to note that Škaljic stresses that burqa and niqab have often been mixed up. The main difference lies in the material. The niqab is made out of basma fabric, cloth or silk, and the burqa is made using felt exclusively (Škaljić 1966: 647). The burqa was also worn in central and south Albania in the second half of the 1920s; Women would wear, or rather don it on their heads, while they would lift the sleeves one over the other on top of their heads, and then leave the house like that with a yaşmak on their head (Dizdar 2005: 268). By donning the burqa in this way, instead of actually putting it on, it was easier for the woman to go short distances - in this way her head was covered, and she covered her face by holding the edges of the burqa with her hands.

Even though the transformation had started taking place, certain clothing elements continued to undergo changes as a result of government restrictions and decisions, especially in the 1950 s, and this was true for virtually the entire territory of the former socialist federation. It is interesting to note the efforts for doing away with the burqa and the niqab, which took root in Bosnia and Herzegovina as early as the era of the Kingdom of Yugoslavia. An article talks openly about the failed attempts to convince Muslim women in Bosnia and Herzegovina: at the $20^{\text {th }}$ congress of the Women's Antifascist Front (AFŽ), held in 1947 in Sarajevo, a resolution was adopted that urged women to remove the burqa. It was all arranged for Muslim women to appoint members of their own community to promote this movement; the Communist Party of the Soviet Union had implemented a similar tactic in its Central Asian republics. However, the campaign failed to bear fruit. A report of the Vlasnica branch of the AFŽ sent to the Sarajevo headquarters shows that during the rally in the town, after the talk on the resolution adopted at the congress, only one woman removed her niqab even though she was a

7 yaşmak (Turkish) - a thin mesh used by Muslim women to cover their head, their face up to their eyes and their chest; çember (Turkish) - a white chiffon headscarf that, together with the yaşmak, makes up a niqab 
member of "one of the most respected Muslim families in the town". In such circumstances, the only alternative that they had left was to introduce a law banning the burqa and the niqab. Thus, in the summer of 1950, this issue was first discussed at the session of the Legislative Board of the national parliament of the National Republic of Bosnia and Herzegovina, presided by Džemal Bijedić. And on September 28 of the same year, the parliament of the National Republic of Bosnia and Herzegovina adopted the Law on Banning Niqabs and Burqas 9 . After the successful adoption of the law, the campaign continued in other communities inhabited by Muslims. Campaigns were implemented in similar circumstances and virtually simultaneously in Macedonia, as well. It was already known that the religious officials, such as the hoca, would be able to convince the people that if women revealed their faces, they would not be in violation of the holy books. The Tetovo Islamic Religious Community held a lecture among the citizens on the subject of the statement by the Grand Mufti of the Islamic Religious Community of the Federal National Republic of Yugoslavia and the ulema council, as well as the Islamic Religious Community of the Republic of Macedonia. Hocas Hasan Efendi and Remzi Tala also joined the discussions. In his address, Hassan Efendi pointed out that the Muslim faith does not teach that female Muslims must wear a burqa ("Sharr" 1950: 3). "At the end of the conference, a resolution was passed according to which male and female Shqiptars from our city are more than happy to accept the initiative of working Muslims from the National Republic of Bosnia and Herzegovina, Kosovo-Metohija and the other regions in our Republic to do away with the burqa" ("Sharr" 1950: 3). The following statement was used to explain the reasons behind this massive campaign: "By wearing a burqa, the female Shqiptar remains quite backward culturally and politically, and by removing the burqa she is given an opportunity to leave such life behind and start a new, happier life" ("Sharr" 1950: 3). The law affected not only female Albanians, but also female Turks, even though the focus was on female Albanian Muslims, who were referred to specifically. After the discussions and conferences, on January 12, 1951, the Law on Banning Niqabs and Burqas was enacted in the People's Republic of Macedonia. According to the first article of the law, "Acting upon the request of the populace to abolish the age-old symbol of submission and cultural delay of female Muslims and in order to provide full equality and broad participation in the societal, cultural and economic life of the country, the wearing of niqab and burqa and any covering of the face of women shall be banned" (Official Journal of the People's Republic of Macedonia, No. 1, January 12, 1951). The sentencing guidelines for each violation of this law were arrest for up to three months or a fine of up to 20,000 dinars (Official Journal of the People's Republic of Macedonia, January 12, 1951, No. 1, article 3). This measure

8 https://vidovdan.org/info/komunisticki-zakon-o-zabrani-zara-i-feredze-od-pre68-godina-i-dalje-vazi-u-bosni- hercegovini/?fbclid=IwARoUTdXJn_yDpCqauBCtZLDWevVFRxo3m7GOsOWgoLYw8plS20Orl4HgwaI

9 https://vidovdan.org/info/komunisticki-zakon-o-zabrani-zara-i-feredze-od-pre68-godina-i-dalje-vazi-u-bosni- hercegovini/?fbclid=IwARoUTdXJn_yDpCqauBCtZLDWevVFRxo3m7GOsOWgoLYw8plS20Orl4HgwaI 
certainly had a share in the removal of the niqab and burqa, but, on the other hand, it helped the terlik gain momentum. I was quite surprised when, during field research in September 2016, in Gorno Jabolchishte, a village near Veles, I noticed that all women wore an older version of terlik, like the one that I had seen as a child, and that I was seeing now, again, but in a different era. This type of garment is made up of two separate pieces. The bottom piece is wider and not so long, has folds and is tied around the waist with a string, and the top piece is partially attached to the bottom one, like a sleeved shirt, and is donned over the head, as the susti (the type of button that is snapped shut by pushing both halves together) for buttoning and unbuttoning can be found only on the top piece. The other type of terlik is more widely distributed. It is simpler, one-piece and resembles the common coat, and has susti for buttoning and unbuttoning. The colour is virtually never altered, but when it is to be worn by young brides, it is crafted and embroidered using various colors and motifs, and thus becomes part of the traditional brides' costume. Within ex-Yugoslavia, a similar campaign was taking place in Kosovo, as well. There, as everywhere else, by rejecting the burqa, the veiled women changed their clothing style. Namely, they started wearing square headscarves, folded diagonally to form a triangle, which they would put on their head and tie below their chin, thus covering the hair, which is in line with Islam canon (women are forbidden to show their hair). Norwegian anthropologist Berit Backer resided in the village of Isnic in Kosovo in the 1970s, in the era when the changes due to the current ideology and the rejection of the headscarf took place. Backer, as an anthropologist, remarks "The expression Nuk kam havale (I don't have a veil) in the social sense is the unofficial declaration of women's liberation used sometimes rather demonstratively by younger females. The Party headed the campaign against the real veil, whereas the social liberations of their thirties who went to school. They met great resistance in the village, but with the support of their family insisted on continuing their education and thus expanding their territory" (Backer 2003: 40). Backer, while talking to a woman married to a member of the Communist party, elucidates the double mentality, the one of the party, as well as the one of the family, even the setting, as well as the clash between them (Backer 2003: 99-100) ${ }^{10}$. The word havale is used figuratively, but in essence it means "to cloak, to cover ", and in the sense of the traditional costume it means "veiled" (Škaljič 1966: 322)"1.

10 My husband later became a member of the 'Party,' which was not very popular with his family. He was expelled in 1953, not because he disagreed with the Party, but because he refused to have my veil removed. He didn't dare to because of the other men in the family. The members of the Party used to go up to women on the street and tear their veils off by force. I can tell you that, many a time, the villagers were close to shedding blood. I remember the first time I went out without a veil. I felt it was the most embarrassing thing I had ever done. But you get used to it. It was a good reform".

11 Havale is an Arabic term and is used figuratively; its core meaning is that it is a fence on the wall that prevents people from looking at the neighbor's alley or house; figuratively, "there is no havala between us" means the women of the two families are not hiding in front of the men. That signifies close friendship, as Muslim women would hide (cover themselves) in front of other husbands < havale "delegate, transfer, refer: a hideout from the other people's 
The influences and the changes to the traditional costume and culture threatened the preservation of the cultural heritage of Albanians, but, regardless, they managed to preserve them partially, as the traditional costume is still used, especially for the more significant traditions and the birth, wedding and death rites, even though it is slowly fading away ${ }^{12}$.

Recently, another type of traditional costume is becoming popular in Macedonia. This costume is neither part of the cultural heritage of the Albanians nor it is in the spirit of their tradition. The traditional costume, or more precisely the fact that they cover their heads and faces with a burqa (feredze) and niqab are not national symbols, they are far removed from the spirit of religious teaching, and they are certainly disassociated and alien from a cultural point of view.

\section{Conclusion}

The transformation of the traditional costume, as well as of the cultural heritage as a whole, ought to be an organic process that occurs with the passage of time. Historic reviews elucidate this transformation, that is linked to other processes and values. More specifically, the individual is not merely a cultural unit, she/he is part of a broader community and as such thrives with her/ his convictions, mentality and awareness. Thusly coupled, the unit and the community do not accept changes in terms of the tradition they have a spiritual bond with, but the unit subconsciously changes, develops and accepts foreign elements. That was evident in the Turkish example, where changes to the rules that govern the fez were introduced in order to make the country seem modern and to establish a modern state. However, in contrast to Atatürk's rule and the reforms he introduced, president Erdoğan has recently introduced changes to the way the headscarf is worn: "Prime minister Recep Tayyip Erdoğan announced that the ban, that was clashing with the spirit of Turkey, shall be abolished. The ban, which was in force since 1925 , shall still pertain to the judiciary and the army"13.

eyes, fences on the wall as a barrier for preventing other people watching you"; < ar. hawala: transfer, changes.

12 The issue of the tërllok/terleme and identity has been mentioned by philosopher Arbër Xhaferi. In his book entitled Në Tetovë, në kërkim të kuptimit, he states: "The hat is one of the symbols that designate national identity. If you change that, you're also altering your national identity by default. Say, if an Albanian was to accept to cover his head with a Serbian hat, the so-called "shajkacha", he would be identified by the others as a Serb, and vice versa, if a Serbian was to wear a white qeleshe, he would be perceived as an Albanian right off the bat. Consequently, these hypothetical situations do not occur in reality except for in theatre plays or in movies, where the costume design, via the clothing, identifies the ethnic belonging of the characters. However, it is peculiar that these principles do not apply when it comes to the borrowing from other peoples. A myriad of Albanians are not aware that the hats they are wearing, the well-known tërllok/terleme, belong to the Semites, the Arab Jews". http://koha. net $/$ ?id $=8 \&$ arkiva $=1 \& \mathrm{l}=98823<:-31.9 .2016$.

13 https://www.akademik.mk/erdogan-ja-ukina-zabranata-za-nosene-shamii-nadrzhavnite-sluzhbenichki-4/ 
Albania, on the other hand, believed the fez and the other Ottoman symbols to be alien and unpatriotic, something that did not fit the national character of the state. Macedonia, as part of the former Yugoslav states, legally banned niqab and burqa, which was already banned in Bosnia and Herzegovina, in order to promote the socialist state and improve the position of women in politics and in social life.

It should be clear that if people, as a community, may fear rejecting some customs and traditions because they think they will not be the same. Perhaps that is the root cause for the resistance in that period in terms of wearing the traditional costume as a symbol of faith, and we are aware that we are witnessing the same situation today because the ban on certain customs that the church believes are pagan is ignored (for example, we have stopped observing the tradition of lighting fire on Christmas Eve, or the removal of the martinka ${ }^{14} \mathrm{etc}$.).

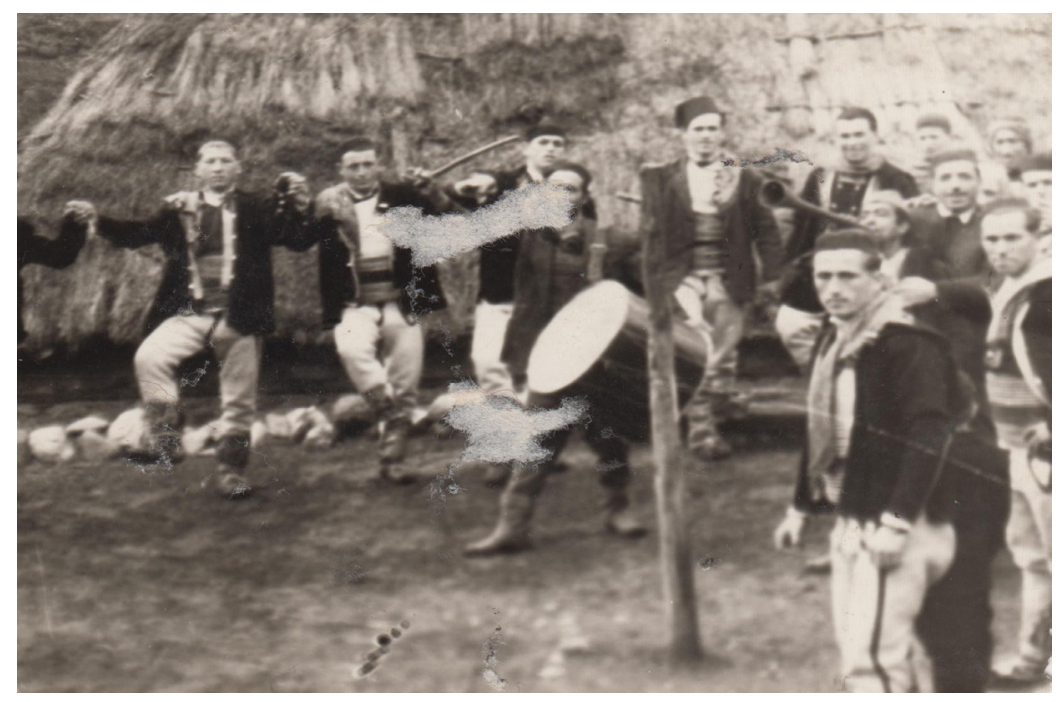

Albanian wedding. From the family album of the Bekiri family Erdzuman Bekiri. Patishka village, 1963.

14 The 'martinka' are crafted using red and white thread that are intertwined and wrapped around the wrist or hangs on clothing until the blossoming of the first tree. It is believed that when the first tree blossoms, the 'martinka' is hooked on the tree and the person wishes good health to the entire family. 
EthnoAnthropoZoom

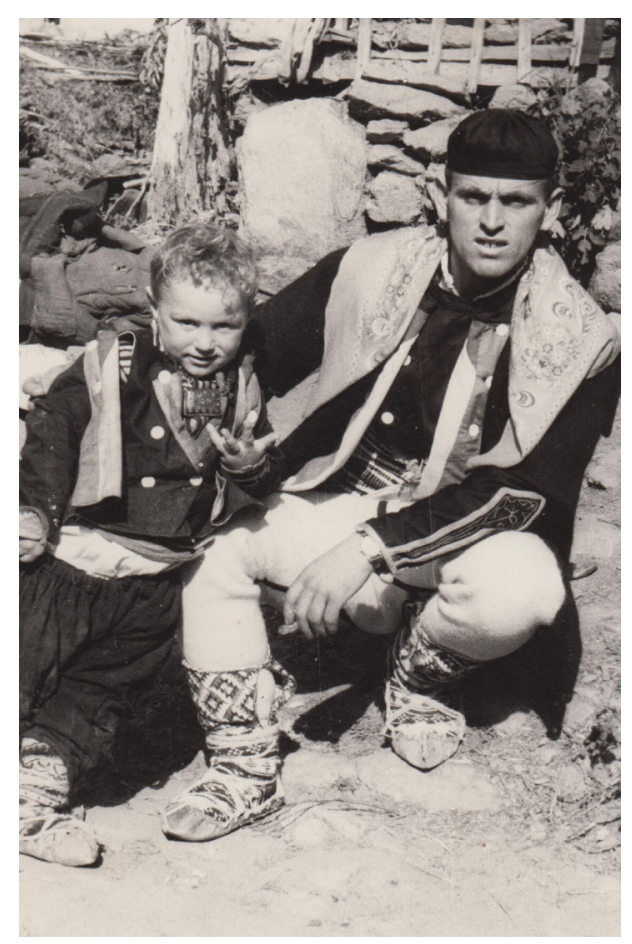

Male traditional costume with a tërllok/terleme on the head.

From the family album of the Bekiri family. Patishka village, 1963. 
EthnoAnthropoZoom

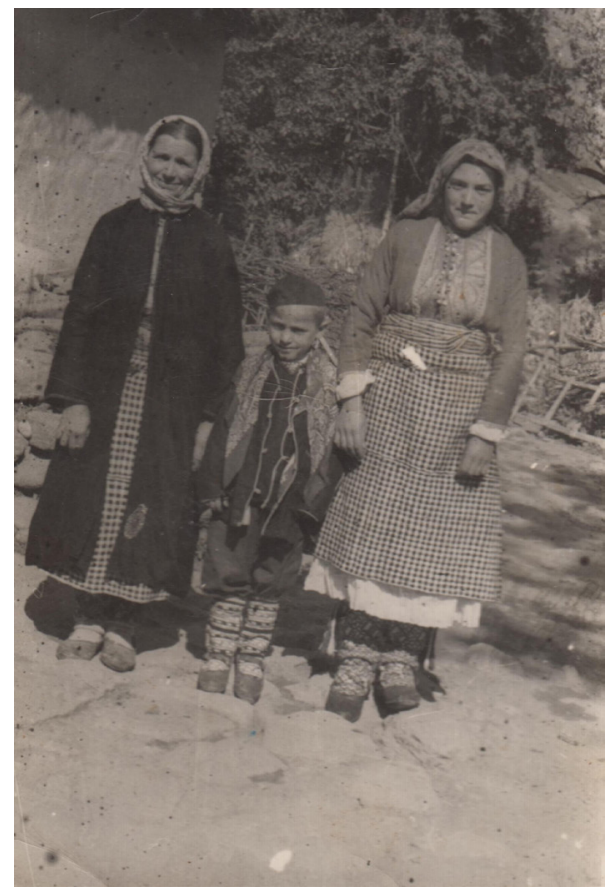

A woman wearing a terlik in the village of Patishka in the 1960 . From the Bekiri family album. Patishka village, 1963. 
EthnoAnthropoZoom

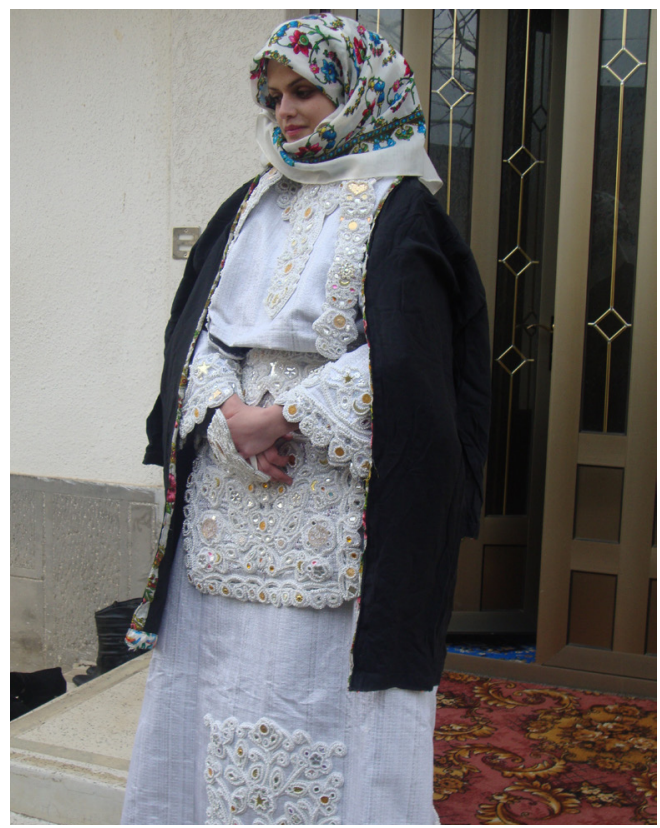

A photograph showing a wedding dress from Kichevo and a terlik.

Shumovo village, Kichevo area, 2010.

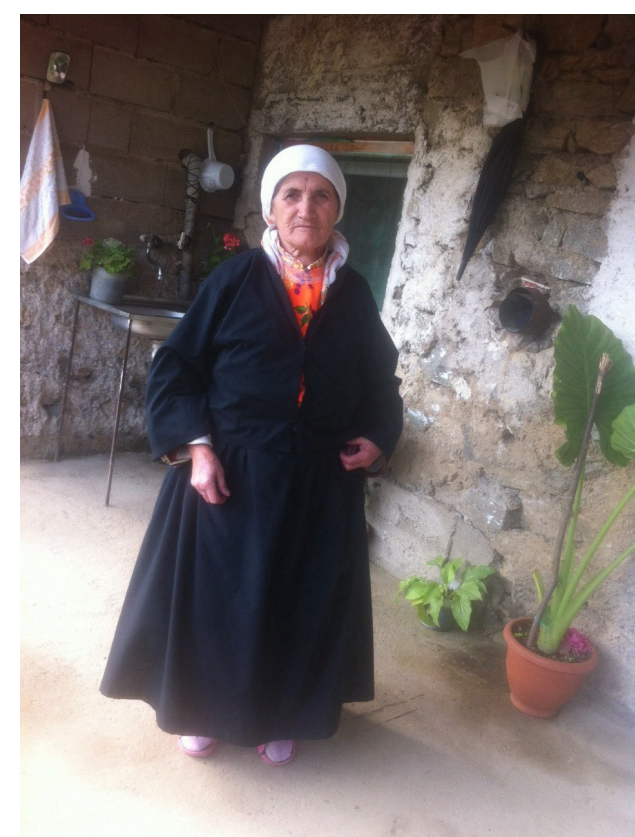

A woman wearing a terlik. Gorno Jabolchishte village, Veles area, 2016. 


\section{Interlocutors}

Istref Bekjiri, Patishka village (1928 - 2015).

Abdul Mustafa, Skopje 1949.

Hakan Turkan, Karabük Üniversitesi, sector: history.

Muharrem Yahya, orientalist, Albanian Spiritual and Cultural Heritage Institute.

\section{Sources}

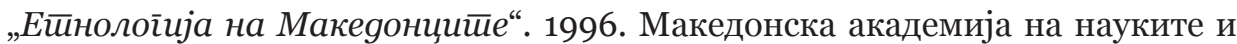
уметностите, Скопје.

„Закон за забрана gа се носи зар и фереце“,Службен весник на Народна Република Македонија, бр. 1, г. VII, петок, 12 јануари 1951 г.

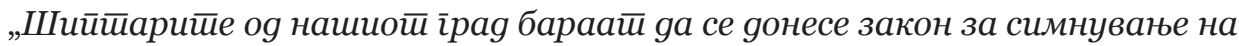
ферецейо“, 8 септември 1950. Весник ШАP-Sharr 3, Тетово.

Комунистички закон о забрани зара и фереџе од пре 68 година и даље важи у Босни и Херцеговини, https://vidovdan.org/info/komunistickizakon-o-zabrani-zara-i-feredze-od-pre-68-godina-i-dalje-vazi-u-bosni-i-hercegovini/?fbclid=IwARoUTdXJn yDpCqauBCtZLDWevVFRxo3m7GOsOWgoLYw8plS20Orl4HgwaI

Ердоган ја укина забраната за носење шамии на државните службенички https://www.akademik.mk/erdogan-ja-ukina-zabranata-za-noseneshamii-na-drzhavnite-sluzhbenichki-4/

Dinarske narodne nošenje“, Narodni.net/dinarske-narodne-nosnje

„Në Tetovë, në kërkim të kuptimit“, http://koha. net $/$ id $=8 \&$ arkiva $=1 \& l=98823<$ : 


\section{References}

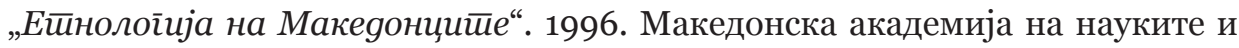
уметностите, Скопје.

Филиповић, Миленко. 1931. „Патишка“, Јужни ӣpeĩлeg 4: 163-174. Скопље.

Asani, Skender. 2013. Gjurmë nëpër kohë. Shkup.

Backer, Berit. 2003. Behind Stone Walls - Changing household organization among the Albanians in Kosova, Peja: Dukagjini Balkan Books.

Dizdar, Tahir. 2005. Fjalor i orientalizmave në gjuhën shqipe. Tiranë: Instituti Shqiptar i Mendimit dhe i Qytetërimit Islam (AIITC).

Gjergji, Andromaqi. 2004. Albanian costumes through the centuries - Origin, types, evolution. Tirana: Academy of Sciences of Albania, Institute of Folc Culture.

Gjergji, Andromaqi. 2005. Veshjet shqiptare në shekuj. Akademia e Shkencave e Shqipërisë, Tiranë: Instituti i Kulturës Popullore.

Ibrahimi, Nexhat. 2017. Fjalor Enciklopedik Islam. Shkup: Logos-A.

Korça, Myxhahid. 2009. Fjalor shqip-turqisht-Arnavutça Sözlük. Shkup: LogosA.

Lubonja, Fatos. 2002. Between the glory of a virtual world and the misery of a real world. Albanian Identities, Myth and History, 91-103. London: Hurst\&Company.

McCarthy, Justin, 2017. Popujt osmanë dhe fundi i Perandorisë. Tiranë. 
Mustafa, Bukurije, Murtezani, Izaim, Useini, Rini. 2017. Gjurmëve tëveshjes popullore shqiptare në Maqedoni. Shkup: Instituti i Trashëgimisë Shpirtërore e Kulturore të Shqiptarëve.

Selimi-Osmani, Edibe. 2012. Veshja autoktone e femrave të Rekës së Epërme; Authentic clothing of women from Reka e Epërme. I, Tetovë. (Bilingual edition).

Skok, Petar. 1971. Etimologijski rječnik hrvatskoga ili srpskoga jezika. Zagreb: Jugoslavenska akademija znanosti i umjetnosti.

Škaljić, Abdulah. 1966. Turcizmi u srpskohrvatskom jeziku. „Svjetlost“, Sarajevo.

Yilmaz, Fehmi. 2010. Osmanl Tarih Sözlüğü. Istanbul: Gökkubbe. 